\title{
Clinical spectrum of POLR3-related leukodystrophy caused by biallelic POLR1C pathogenic variants
}

Laurence Gauquelin, MD, FRCPC,* Ferdy K. Cayami, MD,* László Sztriha, MD, PhD, Grace Yoon, MD, FRCPC, Luan T. Tran, MSc, Kether Guerrero, MSc, François Hocke, MD, Rosalina M.L. van Spaendonk, PhD, Eva L. Fung, MB, ChB, Stefano D'Arrigo, MD, Gessica Vasco, MD, PhD, Isabelle Thiffault, PhD, FACMG, Dmitriy M. Niyazov, MD, Richard Person, PhD, FACMG, Kara Stuart Lewis, MD, Evangeline Wassmer, MD, MSc, Trine Prescott, MD, Penny Fallon, MBBS, MRCPCH, Meriel McEntagart, MD, Julia Rankin, MD, PhD, Richard Webster, MBBS, MSc, FRACP, Heike Philippi, MD, Bart van de Warrenburg, MD, PhD, Dagmar Timmann, MD, Abhijit Dixit, MD, and Claire Searle, MB ChB, MRCP, DDD Study, Nivedita Thakur, MD, Michael C. Kruer, MD, Suvasini Sharma, MD, DM, Adeline Vanderver, MD, Davide Tonduti, MD, PhD, Marjo S. van der Knaap, MD, PhD, Enrico Bertini, MD, Cyril Goizet, MD, PhD, Sébastien Fribourg, PhD, Nicole I. Wolf, MD, PhD, $¥$ and Geneviève Bernard, MD, MSc, FRCPC

Neurol Genet 2019;5:e369. doi:10.1212/NXG.0000000000000369

\section{Abstract}

\section{Objective}

To determine the clinical, radiologic, and molecular characteristics of RNA polymerase III-related leukodystrophy (POLR3-HLD) caused by biallelic POLR1C pathogenic variants.

\section{Methods}

A cross-sectional observational study involving 25 centers worldwide was conducted. Clinical and molecular information was collected on 23 unreported and previously reported patients with POLR3-HLD and biallelic pathogenic variants in POLR1C. Brain MRI studies were reviewed.
Correspondence

Dr. Bernard

genevieve.bernard@mcgill.ca

\begin{abstract}
*These authors contributed equally to the manuscript.
$\ddagger$ Dual senior authors.

From the Department of Neurology and Neurosurgery (L.G., L.T.T., K.G., G.B.), McGill University, Montreal, Canada; Department of Pediatrics (L.G., L.T.T., K.G., G.B.), McGill University, Montreal, Canada; Division of Clinical and Metabolic Genetics and Division of Neurology (L.G., G.Y.), The Hospital for Sick Children, University of Toronto, Toronto, Canada; Department of Child Neurology (F.K.C., M.S.V.D.K., N.I.W.), Emma Children's Hospital, Amsterdam University Medical Centers, Vrije Universiteit Amsterdam, and Amsterdam Neuroscience, Amsterdam, The Netherlands; Department of Clinical Genetics (F.K.C., R.M.V.S.), VU University Medical Center, Amsterdam, The Netherlands; Department of Human Genetics (F.K.C.), Center for Biomedical Research, Diponegoro University, Semarang, Indonesia; Department of Pediatrics (L.S.), Faculty of Medicine, University of Szeged, Szeged, Hungary; Child Health and Human Development Program (L.T.T., K.G., G.B.), Research Institute of the McGill University Health Center, Montreal, Canada; Division of Medical Genetics, Department of Specialized Medicine (L.T.T., K.G., G.B.), McGill University Health Center, Montreal, Canada; Centre de Référence Neurogénétique (F.H., C.G.), Service de Génétique, CHU Bordeaux, Bordeaux, France; Department of Pediatrics (E.L.F.), Faculty of Medicine, The Chinese University of Hong Kong, Hong Kong, China; Developmental Neurology Department (S.D.A.), Fondazione IRCCS Istituto Neurologico C. Besta, Milan, Italy; Neuroscience and Neurorehabilitation Department (G.V.), Bambino Gesu Children's Hospital, Rome, Italy; Center for Pediatric Genomic Medicine (I.T.), Children's Mercy Hospitals and Clinics, Kansas City, MO; University of Missouri-Kansas City School of Medicine (I.T.), Kansas City, MO; Department of Pathology and Laboratory Medicine (I.T.), Children's Mercy Hospitals, Kansas City, MO; Department of Pediatrics (D.M.N.), Section of Medical Genetics, Ochsner for Children, New Orleans, LA; GeneDx (R.P.), Gaithersburg, MD; Division of Neurology (K.S.L.), Barrow Neurological Institute, Phoenix Children's Hospital, Phoenix, AZ; Department of Pediatric Neurology (E.W.), Birmingham Children's Hospital, Birmingham, United Kingdom; Department of Medical Genetics (T.P.), Telemark Hospital, Skien, Norway; Department of Paediatric Neurology (P.F.), St Georges University Hospital NHS Foundation Trust, London, United Kingdom; Clinical Genetics Service (M.M.), St George's University Hospitals NHS Foundation Trust, London, United Kingdom; Clinical Genetics Department (J.R.), Royal Devon and Exeter Hospital NHS Trust, Exeter, United Kingdom; Department of Neurology and Neurosurgery (R.W.), The Children's Hospital at Westmead, Westmead, New South Wales, Australia; Center of Developmental Neurology (H.P.), Frankfurt, Germany; Department of Neurology (B.V.D.W.), Donders Institute for Brain, Cognition and Behaviour, Radboud University Medical Center, Nijmegen, The Netherlands; Department of Neurology (D.T.), Essen University Hospital, University of Duisburg-Essen, Essen, Germany; Department of Clinical Genetics (A.D., C.S.), Nottingham University Hospitals NHS Trust, Nottingham, United Kingdom; Wellcome Sanger Institute (DDD Study), Wellcome Genome Campus, Cambridge, United Kingdom; Department of Pediatrics (N.T.), Division of Child Neurology, University of Texas Health Science Center, Houston, TX, United States of America; Movement Disorders Center and Neurogenetics Research Program (M.C.K.), Barrow Neurological Institute, Phoenix Children's Hospital, Phoenix, AZ; Program in Neuroscience (M.C.K.), Arizona State University, Tempe, AZ, United States of America; Division of Neurology (S.S.), Department of Pediatrics, Lady Hardinge Medical College and Associated Kalawati Saran Children's Hospital, New Delhi, India; Division of Neurology (A.V.), Children's Hospital of Philadelphia, Philadelphia, PA; Department of Neurology (A.V.), Perelman School of Medicine, University of Pennsylvania, Philadelphia, PA, United States of America; Department of Child Neurology (D.T.), Neurological Institute C. Besta Foundation IRCCS, Milan, Italy; Department of Functional Genomics (M.S.V.D.K.), VU University, Amsterdam, The Netherlands; Unit of Neuromuscular and Neurodegenerative Disorders (E.B.), Laboratory of Molecular Medicine, Bambino Gesu Children's Hospital, Rome, Italy; Laboratoire MRGM, INSERM U1211, University Bordeaux, Bordeaux, France; Université de Bordeaux (S.F.), INSERM U1212, CNRS 5320, Bordeaux, France; and Department of Human Genetics (G.B.), McGill University, Montreal, Canada.
\end{abstract}

Go to Neurology.org/NG for full disclosures. Funding information is provided at the end of the article.

The Article Processing Charge was funded by the Canadian Institutes of Health Research.

This work was presented as a poster at the 46th Annual Child Neurology Society Meeting, Kansas City, MO (2017). An abstract was published in Annals of Neurology.

This is an open access article distributed under the terms of the Creative Commons Attribution-NonCommercial-NoDerivatives License 4.0 (CC BY-NC-ND), which permits downloading and sharing the work provided it is properly cited. The work cannot be changed in any way or used commercially without permission from the journal. 


\section{Glossary}

POLR3-HLD = RNA polymerase III-related leukodystrophy; TCS = Treacher Collins syndrome.

\section{Results}

Fourteen female and 9 male patients aged 7 days to 23 years were included in the study. Most participants presented early in life (birth to 6 years), and motor deterioration was seen during childhood. A notable proportion of patients required a wheelchair before adolescence, suggesting a more severe phenotype than previously described in POLR3-HLD. Dental, ocular, and endocrine features were not invariably present $(70 \%, 50 \%$, and $50 \%$, respectively). Five patients $(22 \%)$ had a combination of hypomyelinating leukodystrophy and abnormal craniofacial development, including 1 individual with clear Treacher Collins syndrome (TCS) features. Brain MRI revealed hypomyelination in all cases, often with areas of pronounced T2 hyperintensity corresponding to $\mathrm{T} 1$ hypointensity of the white matter. Twenty-nine different pathogenic variants (including 12 new diseasecausing variants) in POLR1C were identified.

\section{Conclusions}

This study provides a comprehensive description of POLR3-HLD caused by biallelic POLR1C pathogenic variants based on the largest cohort of patients to date. These results suggest distinct characteristics of POLR1C-related disorder, with a spectrum of clinical involvement characterized by hypomyelinating leukodystrophy with or without abnormal craniofacial development reminiscent of TCS.

Leukodystrophies are a heterogeneous group of genetically determined disorders affecting the cerebral white matter, with or without involvement of the peripheral nervous system. ${ }^{1,2}$ Hypomyelinating leukodystrophies, characterized by a severe and permanent myelin deficit, form a large subgroup within the leukodystrophies. ${ }^{3-5}$

RNA polymerase III-related leukodystrophy (POLR3-HLD) is typically characterized by a combination of neurologic and non-neurologic manifestations. ${ }^{6,7}$ Cerebellar features are usually prominent, with pyramidal signs involving the lower more than the upper extremities. The non-neurologic manifestations include dental abnormalities, endocrine features, and myopia. ${ }^{6}$ Brain MRI generally shows diffuse hypomyelination (mild T2 hyperintensity and variable T1 signal intensity of the white matter) with relative myelin preservation (T2 hypointensity) of specific structures. ${ }^{4-6,8}$ Cerebellar atrophy and thinning of the corpus callosum are common associated findings. ${ }^{6,8}$

POLR3-HLD is an autosomal recessive disorder. It was first associated with pathogenic variants in POLR3A or POLR3B, encoding the largest subunits of RNA polymerase III. ${ }^{6,9-13}$ It was also recently associated with a homozygous pathogenic variant in POLR3K.$^{14}$ In 2015, variants in POLR1C, encoding a common POLR1 and POLR3 subunit, were identified in 8 patients with POLR3-HLD. ${ }^{15}$ Pathogenic variants in POLR1C were previously associated with autosomal recessive Treacher Collins syndrome (TCS), a congenital disorder of craniofacial development, in 3 unrelated patients. ${ }^{16}$

To date, the clinical spectrum of POLR3-HLD caused by biallelic POLR1C pathogenic variants has not been described in detail. We present a thorough phenotypic description of this condition by reporting the clinical, imaging, and molecular features of 23 genetically proven cases.

\section{Methods}

Twenty-three individuals were included in this multicenter cross-sectional study. The participants were recruited between 2016 and 2018 based on their clinical and radiologic features consistent with POLR3-HLD, combined with proven pathogenic variants in POLR1C. They were recruited from 25 different centers worldwide. Eight of the 23 patients have previously been published in the original article identifying POLR1C as a causative gene for POLR3HLD, in 2015. ${ }^{15^{\circ}}$

A retrospective chart review was conducted for each participant. Participants of all ages were included in the study. Clinical and demographic information was collected through a questionnaire distributed to the referring physicians. Sex was documented as observed by the physicians. Consanguinity as well as ethnicity and/or country of origin were also assessed, as reported by the participants and their families.

Brain MRI studies of 22 participants were reviewed by G.B. and L.G. (11), N.I.W. (10), or D.T. (1). MRI was not available for 1 individual who died in the neonatal period. The available studies were analyzed based on established criteria for hypomyelination and previously published imaging characteristics of POLR3-HLD. ${ }^{4-6,8}$ Biallelic pathogenic variants in POLR1C were identified or confirmed in clinically certified laboratories. The human genome version used for annotation was GRCh37/hg19. 
Figure 3B was generated using the Lollipops software. ${ }^{17}$ To generate figure $3 \mathrm{C}$, the sequences of human POLR1C and yeast RPAC40 were aligned using Seaview. ${ }^{18}$ The yeast equivalent residues found mutated in patients were identified using the sequence alignment and were positioned on the yeast RPAC40 taken from the POLR1 structure (PDB 5M5W). ${ }^{19}$ Figure $3 \mathrm{C}$ was created using Pymol. ${ }^{20}$

\section{Standard protocol approvals, registrations, and patient consents}

Written informed consent was obtained from all participants or their legal representatives. Consent was obtained from 1 participant (patient 19) for disclosure of a photograph. The study was approved by the ethics committees of the McGill University Health Center (11-105-PED) and VU University Medical Center (2018.300). The patients and their families did not receive financial compensation for their participation in the study.

\section{Data availability}

The data sets were deposited in a publicly available database (ClinVar number SUB5043960). Anonymized data will be shared by request from any qualified investigator.

\section{Results}

\section{Demographic data}

Twenty-three individuals (14 female and 9 male patients) from 21 families were included in the study. There were 2 consanguineous families (patients 1 and 13). The patients' age at their last clinical assessment ranged from 7 days to 23 years (median 10 years). The demographic characteristics of the 23 participants are reported in table 1 .

\section{Neurologic manifestations}

The clinical characteristics of the participants are summarized in table 1 . The onset of symptoms was in infancy or childhood, ranging from birth to 6 years. Most patients $(17 / 23$, $74 \%$ ) presented in the first 2 years of life, including 4 in the neonatal period. For the majority of participants, the initial symptoms consisted of motor difficulties (delayed motor development, tremor, or gait impairment). Limited information was available on patient 20.2, who died early in the neonatal period (at age 7 days). Of the other 22 individuals, 9 (41\%) did not achieve independent walking, and ambulation was delayed in most of the remaining patients. Nine of 22 participants (41\%) had dysphagia, and 5 of them required a gastrostomy tube (between ages 9 months and 10 years).

On examination, all 22 participants who were evaluated beyond the neonatal period had cerebellar signs (ataxia, dysarthria, dysmetria, intention tremor, and nystagmus), and many had prominent tremor. Pyramidal signs were often more pronounced in the lower extremities (14/22 participants, $64 \%$ ). Dystonia was noted in $7 / 22$ patients (32\%). Cognitive impairment (intellectual disability and/or cognitive regression) was variable, seen in $15 / 21$ individuals $(71 \%)$ who were old enough to be evaluated. Global deterioration with infections was noted in almost half (10/22, 45\%). In addition, seizures were reported in $5 / 22$ patients (23\%), 1 of whom had events during febrile episodes only and was not treated with antiepileptic medication.

Motor regression occurred in most of the patients (16/22, $73 \%)$ and was seen during childhood, between ages 2 and 8 years, except for 2 individuals who experienced regression later (at 12 and 16 years). The use of a wheelchair was often required before adolescence (13/22, 59\%). Two of 23 patients died. One of them died in the neonatal period (patient 20.2), and the other at age 10 years (patient 19), both from cardiorespiratory failure. Both had presented in the neonatal period and exhibited abnormal craniofacial development. Patient 20.2 also had cardiac arrhythmias, respiratory distress syndrome, and suspected adrenal insufficiency.

\section{Non-neurologic manifestations}

Patient 19 was the only one described by the referring clinician as having facial features compatible with TCS, including downslanted palpebral fissures, strabismus, bitemporal narrowing, external ear abnormalities, cleft palate, and prominent micrognathia (figure 1). Four other individuals (patients 2, 3, 17 , and 20.2) showed subtle evidence of abnormal craniofacial development, with mild mandibular hypoplasia. Of note, patient 9 did not exhibit craniofacial abnormalities but had laryngomalacia.

The entire dental, ocular, and endocrine features often seen in POLR3-HLD were not always present, but all patients were found to have at least 1 non-neurologic manifestation. Dental abnormalities were seen in 16/23 individuals (70\%): delayed eruption, oligodontia or hypodontia, abnormal tooth shape, malocclusion, neonatal teeth, or frequent cavities. Half of the patients who were evaluated beyond the neonatal period had myopia $(11 / 22,50 \%)$. Short stature was present in $11 /$ $22(50 \%)$.

\section{Radiologic characteristics}

Radiologic characteristics are presented in table 2 and figure 2. Brain MRI studies were available for $22 / 23$ participants (96\%). All showed diffuse hypomyelination, with relative preservation (T2 hypointensity) of specific structures. Preserved myelination of the anterolateral thalamus was seen in $21 / 22$ individuals (95\%), and optic radiation in $18 / 22(82 \%)$. However, several patients did not exhibit all the radiologic characteristics previously described in POLR3-HLD. Relative myelin preservation was less consistently seen in the posterior limb of the internal capsule $(12 / 22,55 \%)$, dentate nucleus $(12 / 22,55 \%)$, and pallidum (11/22, 50\%). In addition, $12 / 22$ cases $(55 \%)$ showed hypointense medial lemniscus. The presence of myelin islets (better myelinated areas within the white matter, T1 hyperintense and T2 hypointense ${ }^{21}$ ) was also noted in a few patients $(3 / 22,14 \%)$. 
Table 1 Demographic, clinical, and molecular characteristics of 23 patients with POLR3-HLD caused by biallelic POLR1C pathogenic variants

\begin{tabular}{|c|c|c|c|c|c|c|c|c|c|c|c|c|c|c|c|c|c|c|c|}
\hline Patient & CDNA & Protein & DNA & Protein & $\begin{array}{l}\text { Sex/ethnicity } \\
\text { and/or country } \\
\text { of origin }\end{array}$ & $\begin{array}{l}\text { Age at } \\
\text { onset } \\
\text { (y) }\end{array}$ & $\begin{array}{l}\text { Use of a } \\
\text { wheelchair } \\
\text { (y) }\end{array}$ & $\begin{array}{l}\text { Dysphagia/ } \\
\text { G-tube (y) }\end{array}$ & Microcephaly & $\begin{array}{l}\text { Cerebellar } \\
\text { signs }\end{array}$ & $\begin{array}{l}\text { Pyramidal } \\
\text { signs }\end{array}$ & Dystonia & $\begin{array}{l}\text { TCS } \\
\text { phenotype }\end{array}$ & $\begin{array}{l}\text { AbN } \\
\text { craniofacial } \\
\text { e development }\end{array}$ & Myopia & $\begin{array}{l}\text { Dental } \\
\mathrm{AbN}\end{array}$ & $\begin{array}{l}\text { Short } \\
\text { stature }\end{array}$ & $\begin{array}{l}\text { Hypogonadotropic } \\
\text { hypogonadism }\end{array}$ & $\begin{array}{l}\text { c Death } \\
\text { (age) }\end{array}$ \\
\hline a & c.95A>T & p.Asn32lle & c. $95 \mathrm{~A}>\mathrm{T}$ & p.Asn32lle & M/Libyan & 1 & - & $-/-$ & - & + & + & - & - & - & - & + & + & - & - \\
\hline & c.221A>G & p.Asn74Ser & c. $221 A>G$ & p.Asn74Ser & $\mathrm{M} /$ Hungarian & 1 & 6 & $+/ 10$ & - & + & + & - & - & + & - & + & - & NA & - \\
\hline & c. $436 \mathrm{~T}>\mathrm{C}$ & p.Cys146Arg & $\begin{array}{l}\text { c.883- } \\
\text { 885delAAG }\end{array}$ & p.Lys295del & $\begin{array}{l}\text { M/Asian } \\
\text { (Chinese) }\end{array}$ & 1 & - & $+/-$ & + & + & + & + & - & + & - & + & + & $\mathrm{pP}$ & - \\
\hline & c. $77 \mathrm{C}>\mathrm{T}$ & p.Thr26lle & c. $326 \mathrm{G}>\mathrm{A}$ & p.Arg109His & $\begin{array}{l}\text { F/Caucasian } \\
\text { (Armenian) }\end{array}$ & 2 & - & $-1-$ & - & + & + & - & - & - & - & + & - & $\mathrm{pP}$ & - \\
\hline & c.193A>G & p.Met65Val & c. $572 \mathrm{G}>\mathrm{A}$ & p.Arg191Gln & $\begin{array}{l}\text { F/Caucasian } \\
\text { (Australian) }\end{array}$ & 1.5 & 8 & $+/-$ & - & + & + & - & - & - & - & - & + & - & - \\
\hline & $c .326 \mathrm{G}>\mathrm{A}$ & p.Arg109His & c. $970 \mathrm{G}>\mathrm{A}$ & p.Glu324Lys & $\begin{array}{l}\text { F/Caucasian } \\
\text { (Turkish) }\end{array}$ & 4 & 11 & $+/-$ & - & + & + & + & - & - & + & - & + & - & - \\
\hline & c. $395 \mathrm{G}>\mathrm{A}$ & p.Gly132Asp & $\begin{array}{l}\text { c.461_- } \\
\text { 462delAA }\end{array}$ & p.Lys $154 f s * 4$ & $\begin{array}{l}\text { F/Caucasian } \\
\text { (German) }\end{array}$ & 1.2 & 0 & $-1-$ & - & + & - & - & - & - & + & + & + & $\mathrm{pP}$ & - \\
\hline & c. $281 \mathrm{~T}>\mathrm{C}$ & p.Val94Ala & c. $785 \mathrm{~T}>\mathrm{C}$ & p.lle262Thr & $\begin{array}{l}\text { M/Caucasian } \\
\text { (Dutch) }\end{array}$ & 1.2 & 0 & NA & - & + & - & $-M$ & - & - & + & - & - & - & - \\
\hline $\begin{array}{l}9^{b} \\
(303565)\end{array}$ & $c .69+1 G>A$ & $\begin{array}{l}\text { p.Asn24Asnfs55* } \\
\text { (prediction) }\end{array}$ & c. $836 \mathrm{G}>\mathrm{A}$ & p.Arg279Gln & $\begin{array}{l}\text { M/Caucasian } \\
\text { (British) }\end{array}$ & 0 & NA & $+/ 0.75$ & + & + & + & - & - & $-L$ & - & + & - & $\mathrm{pP}$ & - \\
\hline 10.1 & $\begin{array}{l}\text { c.916- } \\
\text { 920delTATAT }\end{array}$ & p.Tyr306Leufs*4 & c. $938 \mathrm{C}>\mathrm{T}$ & p.Thr313Met & M/Caucasian & 4 & - & $-/-$ & - & + & - & - & - & - & - & + & - & - & - \\
\hline 10.2 & $\begin{array}{l}\text { c.916- } \\
\text { 920delTATAT }\end{array}$ & p.Tyr306Leufs*4 & $c .938 \mathrm{C}>\mathrm{T}$ & p.Thr313Met & M/Caucasian & 4 & - & $-/-$ & - & + & - & - & - & - & + & + & - & - & - \\
\hline 11 & c.193A>G & p.Met65Val & c. $733 \mathrm{G}>\mathrm{A}$ & p.Val245Met & $\begin{array}{l}\text { M/Caucasian } \\
\text { (Dutch) }\end{array}$ & 2 & - & $-/-$ & - & + & - & - & - & - & + & - & - & - & - \\
\hline 12 & $c .313 \mathrm{~A}>\mathrm{T}$ & p.lle105Phe & $\begin{array}{l}\text { c.916- } \\
\text { 920delTATAT }\end{array}$ & p. Tyr306Leufs $\star 4$ & $\begin{array}{l}\text { F/Caucasian } \\
\text { (English) }\end{array}$ & 3 & 12 & $-/-$ & + & + & - & - & - & - & + & + & - & $\mathrm{pP}$ & - \\
\hline
\end{tabular}




\begin{tabular}{|c|c|c|c|c|c|c|c|c|c|c|c|c|c|c|c|c|c|c|c|}
\hline Patient & cDNA & Protein & DNA & Protein & $\begin{array}{l}\text { Sex/ethnicity } \\
\text { and/or country } \\
\text { of origin }\end{array}$ & $\begin{array}{l}\text { Age at } \\
\text { onset } \\
\text { (y) }\end{array}$ & $\begin{array}{l}\text { Use of a } \\
\text { wheelchair } \\
\text { (y) }\end{array}$ & $\begin{array}{l}\text { Dysphagia/ } \\
\text { G-tube }(y)\end{array}$ & Microcephaly & $\begin{array}{l}\text { Cerebellar } \\
\text { signs }\end{array}$ & $\begin{array}{l}\text { Pyramidal } \\
\text { signs }\end{array}$ & Dystonia & $\begin{array}{l}\text { TCS } \\
\text { phenotype }\end{array}$ & $\begin{array}{l}\text { AbN } \\
\text { craniofacial } \\
\text { development }\end{array}$ & Myopia & $\begin{array}{l}\text { Dental } \\
\mathrm{AbN}\end{array}$ & $\begin{array}{l}\text { Short } \\
\text { stature }\end{array}$ & $\begin{array}{l}\text { Hypogonadotropic } \\
\text { e hypogonadism }\end{array}$ & $\begin{array}{l}\text { Death } \\
\text { (age) }\end{array}$ \\
\hline $\begin{array}{l}13^{\mathrm{a}, \mathrm{b}} \\
(279603)\end{array}$ & $c .836 \mathrm{G}>\mathrm{A}$ & p.Arg279Gln & c. $836 \mathrm{G}>\mathrm{A}$ & p.Arg279Gln & $\begin{array}{l}\text { F/Caucasian } \\
\text { (English) }\end{array}$ & 2 & 7 & $-/-$ & + & + & + & + & - & - & - & - & + & $\mathrm{pP}$ & - \\
\hline 14 & $c .88 \mathrm{C}>\mathrm{T}$ & p.Pro30Ser & $\begin{array}{l}\text { c.916 } \\
\text { 920deITATAT }\end{array}$ & p.Tyr306Leufs*4 & F/Norwegian & 0.3 & 0 & $-/-$ & - & + & - & + & - & - & + & + & - & $\mathrm{pP}$ & - \\
\hline 15 & c. $221 \mathrm{~A}>\mathrm{G}$ & p.Asn74Ser & $c .502 \mathrm{G}>\mathrm{A}$ & $\begin{array}{l}\text { p.Val168Met + } \\
\text { splicing error }\end{array}$ & $\begin{array}{l}\text { F/Caucasian } \\
\text { (English) }\end{array}$ & 0 & 0 & $+/ 1$ & + & + & + & + & - & - & + & + & + & $\mathrm{pP}$ & - \\
\hline 16 & c.79A>G & p.Thr27Ala & c. $349 \mathrm{G}>\mathrm{C}$ & p.Ala117Pro & F/Caucasian & 6 & - & $-/-$ & - & + & + & - & - & - & - & + & - & - & - \\
\hline 17 & $c .322 \mathrm{C}>\mathrm{T}$ & p.His108Tyr & $c .325 \mathrm{C}>\mathrm{T}$ & p.Arg109Cys & F/Caucasian & 0.4 & 0 & $+/-$ & + & + & + & - & - & + & - & + & - & - & - \\
\hline 18 & c. $70-1 \mathrm{G}>\mathrm{A}$ & $\begin{array}{l}\text { p.Asn24Profs27* } \\
\text { (prediction) }\end{array}$ & $c .835 \mathrm{C}>\mathrm{T}$ & p.Arg279Trp & $\begin{array}{l}\text { F/African } \\
\text { American }\end{array}$ & 2 & 11 & $-1-$ & + & + & + & - & - & - & - & - & + & $\mathrm{pP}$ & - \\
\hline 19 & c. $699 \mathrm{C}>\mathrm{G}$ & p.Tyr233* & $\begin{array}{l}\text { c.883 } \\
\text { 885delAAG }\end{array}$ & p.Lys295del & F/Caucasian & 0 & 3 & $+/ 2$ & + & + & + & + & + & + & + & + & + & $\mathrm{pP}$ & $10 y$ \\
\hline 20.1 & $c .88 \mathrm{C}>\mathrm{T}$ & p.Pro30ser & c.615delC & p.Gln206Lysfs $* 48$ & M/Caucasian & 1 & 4 & $+/ 7$ & + & + & + & + & - & - & $+C$ & + & + & $\mathrm{pP}$ & - \\
\hline 20.2 & $c .88 \mathrm{C}>\mathrm{T}$ & p.Pro30Ser & c.615delC & p.Gln206Lysfs*48 & F/Caucasian & 0 & NA & NA & + & NA & NA & NA & - & + & NA & - & NA & $\mathrm{pP}$ & $7 d$ \\
\hline 21 & c. $77 \mathrm{C}>\mathrm{T}$ & p.Thr26lle & c. $77 \mathrm{C}>\mathrm{T}$ & p.Thr26lle & F/Asian & 3.5 & - & $-1-$ & - & + & - & - & - & - & + & + & + & $\mathrm{pP}$ & - \\
\hline $\begin{array}{l}\text { Abbreviat } \\
\text { Patients } \\
\text { a Consan } \\
{ }^{b} \text { Contrib }\end{array}$ & $\begin{array}{l}\text { ations: } \mathrm{AbN}= \\
1-8 \text { have pre } \\
\text { guinity. } \\
\text { pution of the }\end{array}$ & $\begin{array}{l}\text { abnormal; } C=\text { catar } \\
\text { viously been publish } \\
\text { DDD study. }\end{array}$ & $\begin{array}{l}\text { racts; G-tube } \\
\text { hed. }{ }^{15} \text { Patien }\end{array}$ & $\begin{array}{l}\text { = gastrostomy tube } \\
\text { s } 9 \text { and } 13 \text { have be }\end{array}$ & $\begin{array}{l}\text {; } \mathrm{L}=\text { laryngomalac } \\
\text { een reported in } \mathrm{DE}\end{array}$ & $\begin{array}{l}\text { cia; } M= \\
\text { CIPHER }\end{array}$ & $\begin{array}{l}\text { myoclonus, } N \\
\text { (identifier be }\end{array}$ & $\begin{array}{l}\mathrm{NA}=\text { not availa } \\
\text { etween bracket }\end{array}$ & $\begin{array}{l}\text { lable; } P=\text { puber } \\
\text { ets). Novel disea }\end{array}$ & $\begin{array}{l}\text { rty; } p P=\text { prep } \\
\text { ase-causing v }\end{array}$ & $\begin{array}{l}\text { pubertal; POL } \\
\text { variants are ir }\end{array}$ & $\begin{array}{l}\text { LR3-HLD = } \\
\text { in bold. }\end{array}$ & RNA polyme & erase III-related & & & & & \\
\hline
\end{tabular}


Figure 1 Photograph of patient 19 showing facial features compatible with Treacher Collins syndrome (TCS)

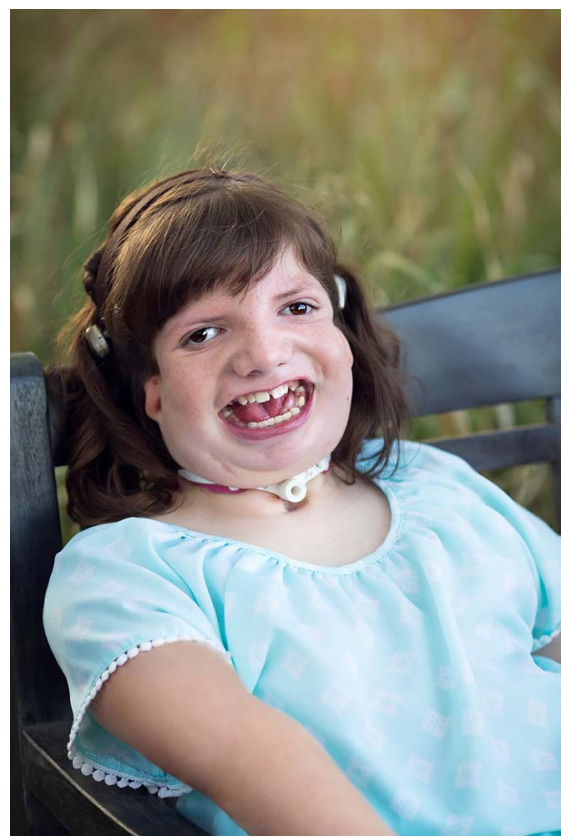

Photograph of patient 19 at age 10 years. She had facial features in keeping with TCS, including downslanted palpebral fissures, strabismus, bitemporal narrowing, external ear abnormalities, cleft palate, and prominent micrognathia.

The vast majority exhibited thinning of the corpus callosum $(21 / 22,95 \%)$ and cerebellar atrophy $(19 / 22,86 \%)$, often mild. Posterior white matter atrophy was present in $7 / 22$ cases (32\%). Diffuse supratentorial atrophy was also seen in $6 / 22$ participants (27\%), without clear correlation with age or clinical severity.

In 16/22 individuals (73\%), MRI revealed areas of prominent $\mathrm{T} 1$ hypointensity of the white matter, which is not typically seen in POLR3-HLD. One patient (patient 20.1) exhibited very atypical MRI features, with pronounced T2 hyperintensity and corresponding $\mathrm{T} 1$ hypointensity of the deep white matter and polymicrogyria.

\section{Molecular findings}

A total of 29 different variants in POLR1C were identified, including missense variants, frameshift variants, and splice site variants (table 1 and figure 3 ). Twelve novel disease-causing variants in POLR1C were identified. Four participants were homozygous, and 19 were compound heterozygous. The most common variants were c.916_920del (p.Tyr306Leufs $\left.{ }^{*} 4\right)$, identified in 4 individuals from 3 unrelated families (patients 10.1, 10.2, 12, and 14), c.88C > T (p.Pro30Ser), in 3 participants from 2 unrelated families (patients 14, 20.1, and 20.2), and c.221A $>\mathrm{G}$ (p.Asn74Ser), in 2 patients from 2 unrelated families (patients 2 and 15). Segregation was confirmed in family members for whom DNA was available for sequencing.

\section{Discussion}

Our findings suggest that POLR3-HLD caused by biallelic POLR1C variants is characterized by a spectrum of clinical features, with hypomyelinating leukodystrophy at times accompanied by craniofacial abnormalities reminiscent of TCS, with varying severity. In addition to the 5 patients who had a combination of neurologic and craniofacial manifestations, 1 patient had laryngomalacia without any other signs of abnormal craniofacial development. Narrowing of the airway is another common manifestation of TCS that is not typically seen in POLR3-HLD. ${ }^{22}$

TCS is a ribosomopathy, and all 3 genes implicated to date (TCOF1, POLR1D, and POLR1C) are involved in pre-rRNA transcription. ${ }^{23}$ Most cases of TCS are caused by heterozygous pathogenic variants in TCOF1. ${ }^{22,24,25}$ Autosomal recessive TCS attributed to pathogenic variants in POLR1C is rare, with only 5 affected individuals reported since $2011 .^{16,26}$ Of these 5 patients, 4 had normal motor development, and there was no information available for the fifth. Brain imaging findings were not reported. $^{16,26}$ POLR3-HLD is known to be associated with variable clinical severity, with later onset and very mild course in some patients. ${ }^{6}$ There is 1 reported patient in the literature with no neurologic signs at age 21 years. ${ }^{6}$ It is also well established that hypomyelination on brain MRI is not obligate in POLR3-related disorder. $^{27-30}$ Therefore, we cannot exclude that the 5 patients with TCS attributed to variants in POLR1C could have a mild form of POLR3-HLD, with only subtle neurologic manifestations, if any. We suspect that there is a spectrum of disease severity for both the hypomyelination and the non-neurologic manifestations in POLR3-HLD caused by biallelic POLR1C variants, as it is the case in patients carrying pathogenic variants in POLR3A or POLR3B. ${ }^{6}$ It is likely that POLR1C-related disorder is underrecognized.

Our patients appeared overall to have a more severe neurologic phenotype than the previously reported patients with POLR3-HLD. ${ }^{6}$ Individuals with biallelic POLR1C variants seem to have the most severe neurologic symptoms, followed by patients with biallelic POLR3A variants. At the other end of the spectrum, $P O L R 3 B$ is known to be associated with milder clinical features. ${ }^{6}$ In our cohort, patients with an earlier onset of symptoms had a more severe clinical course, did not achieve ambulation, and were microcephalic, features that are very rarely associated with TCS. $^{22,24,25}$ There was no clear genotype-phenotype correlation. Two of the 4 patients with onset of symptoms in the neonatal period were also part of the group that had abnormal craniofacial development. Otherwise, the pattern of cerebellar and pyramidal signs seen in most of our 23 patients was consistent with the established phenotype of POLR3-HLD.

Neurologic manifestations are rarely seen in cases of typical TCS caused by heterozygous pathogenic variants in TCOF1. ${ }^{22,24,25}$ Delayed speech development is thought to be secondary to 
Table 2 Brain MRI characteristics of 22 patients with POLR3-HLD caused by biallelic POLR1C pathogenic variants

\begin{tabular}{|c|c|c|c|c|c|c|c|c|c|c|c|c|c|}
\hline Patient & Hypomyelination & $\begin{array}{l}\text { T2 } \\
\text { Hypointense } \\
\text { dentatus }\end{array}$ & $\begin{array}{l}\text { T2 } \\
\text { Hypointense } \\
\text { pallidum }\end{array}$ & $\begin{array}{l}\text { T2 } \\
\text { Hypointense } \\
\text { CST in PLIC }\end{array}$ & $\begin{array}{l}\text { T2 } \\
\text { Hypointense } \\
\text { lateral } \\
\text { thalamus }\end{array}$ & $\begin{array}{l}\text { T2 } \\
\text { Hypointense } \\
\text { optic } \\
\text { radiation }\end{array}$ & $\begin{array}{l}\text { Thin } \\
\text { corpus } \\
\text { callosum }\end{array}$ & $\begin{array}{l}\text { Posterior } \\
\text { white } \\
\text { matter } \\
\text { atrophy }\end{array}$ & $\begin{array}{l}\text { Supratentorial } \\
\text { atrophy }\end{array}$ & $\begin{array}{l}\text { Cerebellar } \\
\text { atrophy }\end{array}$ & $\begin{array}{l}\text { WM areas of } \\
\text { marked T1 } \\
\text { hypointensity }\end{array}$ & $\begin{array}{l}\text { T2 } \\
\text { Hypointense } \\
\text { medial } \\
\text { lemniscus }\end{array}$ & $\begin{array}{l}\text { Other } \\
\text { findings }\end{array}$ \\
\hline | & + & + & + & - & + & + & + & - & + & + & + & + & \\
\hline 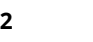 & + & - & - & - & + & + & + & - & - & + & + & + & \\
\hline 3 & + & - & + & - & - & + & + & - & - & + & + & - & \\
\hline 1 & + & + & + & - & + & + & + & - & - & + & + & + & \\
\hline ; & + & - & - & + & + & + & + & - & - & + & + & - & \\
\hline ; & + & + & - & + & + & + & + & + & - & + & + & + & \\
\hline 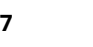 & + & - & - & + & + & + & + & - & - & + & + & - & \\
\hline 3 & + & - & - & + & + & + & + & - & + & + & + & + & \\
\hline 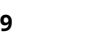 & + & + & - & + & + & + & + & - & + & - & + & + & \\
\hline 10.1 & + & + & + & + & + & + & + & - & - & + & + & + & $\mathrm{MI}$ \\
\hline 10.2 & + & + & + & + & + & + & + & - & - & + & + & + & $\mathrm{MI}$ \\
\hline 11 & + & + & + & + & + & + & + & + & - & + & + & - & \\
\hline 12 & + & + & + & - & + & + & + & + & - & + & - & - & \\
\hline 13 & + & + & + & + & + & + & + & - & - & + & + & - & \\
\hline 14 & + & - & - & - & + & - & - & - & - & - & - & - & \\
\hline 15 & + & - & - & - & + & - & + & - & + & + & - & - & \\
\hline 16 & + & + & + & - & + & + & + & + & + & + & + & + & \\
\hline 17 & + & - & - & - & + & - & + & + & - & + & - & + & \\
\hline 18 & + & + & + & + & + & + & + & - & - & + & + & + & \\
\hline 19 & + & - & + & - & + & - & + & + & + & - & - & + & \\
\hline 20.1 & + & - & - & + & + & + & + & - & - & + & + & - & PMG \\
\hline 20.2 & NA & NA & NA & NA & NA & NA & NA & NA & NA & NA & NA & NA & \\
\hline 21 & + & + & - & + & + & + & + & + & - & + & - & - & $\mathrm{MI}$ \\
\hline
\end{tabular}

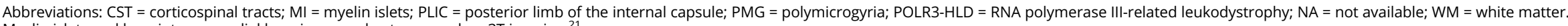
Myelin islets and hypointense medial lemniscus are best assessed on $3 \mathrm{~T}$ imaging. ${ }^{2}$ 


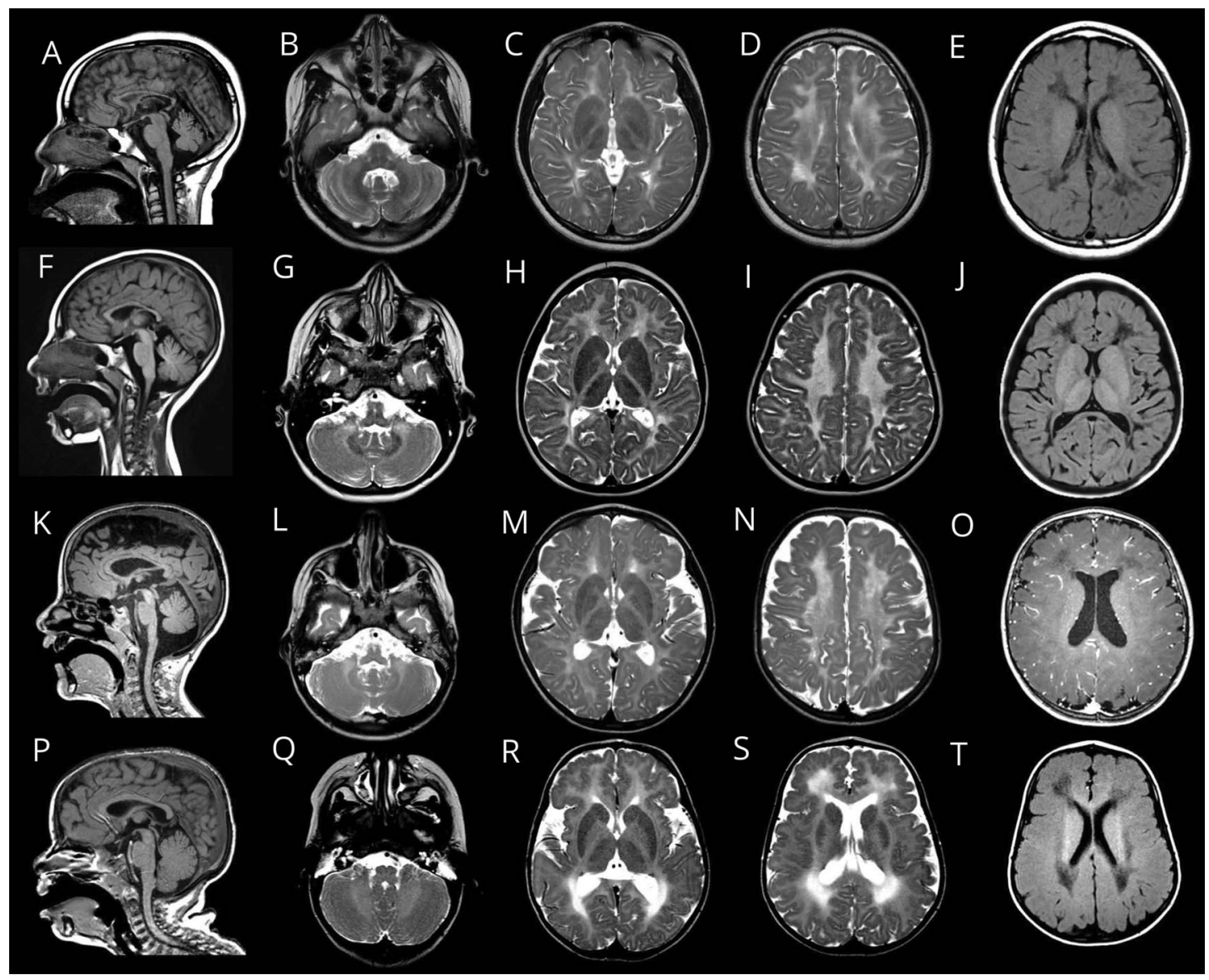

Sagittal T1 (A, F, K, and P), axial T2 (B-D, G-I, L-N, and Q-S) and axial T1 (E, J, O, and T) images. (A-E) MRI of patient 18 obtained at age 11 years showing diffuse hypomyelination with superimposed areas of pronounced $T 2$ hyperintensity $(C$ and $D)$ and corresponding $T 1$ hypointensity (E). Thinning of the corpus callosum and mild superior vermis atrophy are also seen (A), as well as preserved myelination of the dentate nucleus (B), globus pallidus, anterolateral nucleus of the thalamus, and optic radiation (C). (F-J) MRI of patient 4 obtained at age 5 years showing diffuse hypomyelination with preservation of the dentate nucleus $(\mathrm{G})$, anterolateral nucleus of the thalamus, and optic radiation $(\mathrm{H})$. There is also thinning of the corpus callosum and mild vermis atrophy (F). Areas of marked T2 hyperintensity of the white matter are seen ( $\mathrm{H}$ and I), with corresponding pronounced T1 hypointensity (J). (K-O), MRI of patient 1 obtained at age 5 years showing a thin corpus callosum (K), relative preservation of myelination of the dentate nucleus (L), and absent $\mathrm{T} 2$ hypointensity of the corticospinal tracts in the posterior limb of the internal capsule (M). (P-T), MRI of patient 20.1 obtained at age 3 years showing areas of prominent T2 hyperintensity of the white matter $(R$ and $S)$ with corresponding $T 1$ hypointensity $(T)$, especially in the deep white matter. There is also bilateral frontal polymicrogyria (R, S, and T). POLR3-HLD = RNA polymerase III-related leukodystrophy.

conductive hearing loss, and delayed motor development is hypothesized to be associated with atypical and severe TCS presentation. ${ }^{24}$ Intellectual disability is also very uncommon; there are 2 reported cases of TCS with intellectual disability caused by deletions of TCOF1, with the cognitive impairment being attributed to the deletion of contiguous genes. ${ }^{25}$ In addition, there are a few reports of exceptionally severe cases of TCS with craniosynostosis and CNS anomalies (encephalocele and holoprosencephaly). ${ }^{31}$ None of these patients had hypomyelination. Thus, the overlap between POLR3-HLD and TCS appears to be unique to POLR1C-related disorder, although variants in POLR1A, first associated with acrofacial dysostosis (another category of craniofacial malformations), have also recently been identified as causing leukoencephalopathy. ${ }^{32}$

A similar clinical overlap with another category of craniofacial defects was identified in POLR3A-related disorder. Biallelic POLR3A variants were found to cause Wiedemann-
Rautenstrauch syndrome, a neonatal form of segmental progeria associated with growth retardation and abnormal facial features, with some patients also exhibiting progressive neurologic symptoms. ${ }^{33}$ It was suggested that the specific combination of a variant with a strong functional effect on the protein with a milder hypomorphic variant leads to the Wiedemann-Rautenstrauch syndrome phenotype. ${ }^{33}$

Regarding non-neurologic manifestations, our findings reinforce that it is crucial to screen patients with POLR3-HLD for dental abnormalities, myopia, and short stature. The dental abnormalities are varied and can be very subtle. The lower frequency of myopia in our cohort compared with the previously reported patients with POLR3A or POLR3B variants $(50 \%$ vs $87 \%)$ may be at least partly due to the fact that our patients were young. Myopia is known to progress over time in patients with POLR3-HLD and may not have started in the younger patients. 


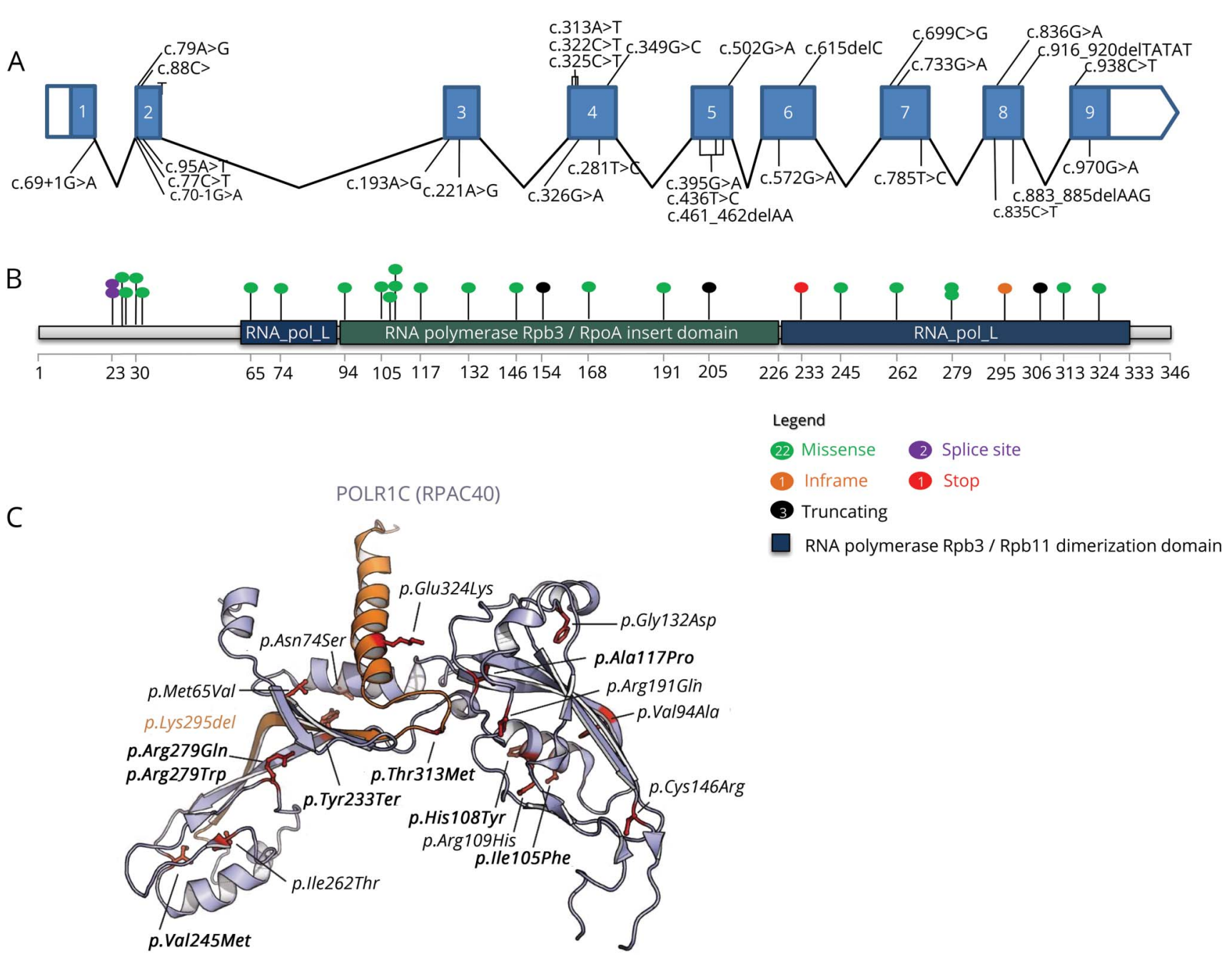

(A-B) All reported pathogenic variants and their positions within the POLR1C gDNA (A), with missense variants represented in green, in frame in orange, truncating in black, splice site in purple, and stop in red (B). (C) Missense variants displayed on the structure of the yeast ortholog of POLR1C (RPAC40). Variants previously identified in POLR3-HLD are represented in italic, whereas newly identified variants are shown in bold. The p.Lys295del is shown in orange. The p.Thr26lle, p.Thr27Ala, and p.Pro30Ser variants have not been represented because they are not visible in the crystal structure of RPAC40 (PDB 5M5W). ${ }^{19,20,38-40}$ POLR3-HLD = RNA polymerase III-related leukodystrophy.

In POLR3-HLD caused by POLR3A or POLR3B variants, brain MRI generally shows diffuse hypomyelination with relative myelin preservation of the anterolateral thalamus, optic radiation, globus pallidus, dentate nucleus, and pyramidal tracts in the posterior limb of the internal capsule. ${ }^{4-6,8}$ In patients carrying POLR $1 C$ variants, the dentate nucleus appeared to be less commonly spared (55\%, compared with $93 \%$ in the literature). ${ }^{6}$ Myelin islets and hypointense medial lemniscus were seen in only $14 \%$ and $55 \%$ of our patients, respectively, however; it is important to mention that these signs are best assessed on $3 \mathrm{~T}$ imaging. ${ }^{21}$ Almost all of our patients exhibited thinning of the corpus callosum, regardless of their age or of the severity of supratentorial atrophy. It is therefore unlikely to represent only the result of diffuse atrophy. Alternatively, it could reflect a more severe underlying white matter involvement. This hypothesis is supported by the characteristic white matter appearance on T1 images in many of our patients, showing areas of more marked hypointensity. In our study, only few of the participants had supratentorial atrophy, which is probably in part due to the fact that they were all comparatively young.

We hypothesize that the atypical MRI characteristics of patient 20.1 could be attributable to 2 distinct conditions, as migration abnormalities have never been formally associated with POLR3-HLD. ${ }^{34}$ Alternatively, it is possible that it represents the more severe end of the neurodevelopmental spectrum. Patient 20.2, the sister of patient 20.1, never underwent a brain MRI as she died in the neonatal period. However, she had atypical clinical features, including cardiac arrhythmias. Cardiac anomalies are reported in several animal models and a few human cases of TCS. ${ }^{22,35}$ In addition, 3 patients were recently diagnosed with POLR1C-related 
disorder in 2 large studies applying whole-exome and wholegenome sequencing to unsolved genetic cases. Their clinical presentation included cardiomegaly, long QT syndrome, and cardiomyopathy. ${ }^{36,37}$

In our cohort, variants were diverse and distributed across POLR1C. Two participants carried the p.Arg279Gln variant previously associated with $\mathrm{TCS}^{16}$ : patient 9 (compound heterozygous with c.69+1G $>$ A) and patient 13 (homozygous). It was initially thought that TCS and leukodystrophy diseasecausing variants were distinct, leading to abnormal localization of POLR1C in the nucleolus and abnormal assembly of the RNA polymerase III, respectively. ${ }^{15}$ However, none of the individuals carrying the TCS pathogenic variant p.Arg.279Gln showed signs of abnormal craniofacial development, raising the question whether the specific genotype combination (compound heterozygosity with p.Arg279Gln) is responsible for the presence or absence of craniofacial abnormalities, but not the p.Arg279Gln itself. Alternatively, a more complex mechanism than the previously described selective defects in POLR1 or POLR3 could be involved. We postulate that other factors, such as genetic modifiers and neonatal exposures, influence the pathophysiology POLR1C-related disorders.

This study provides a comprehensive description of POLR3-HLD caused by biallelic POLR1C pathogenic variants based on the largest cohort of patients to date. We present patients with both a hypomyelinating leukodystrophy and abnormal craniofacial development reminiscent of TCS, suggesting a spectrum of clinical involvement in patients with POLR1C-related disorder. These results illustrate the expansion of a known phenotype in the field of rare diseases.

\section{Acknowledgment}

The authors thank the patients and their families for their participation. They acknowledge Chiara Aiello, $\mathrm{PhD}$, for molecular genetic contribution at the Unit of Neuromuscular and Neurodegenerative Disorders, Laboratory of Molecular Medicine, Bambino Gesu Children's Hospital, Rome, Italy.

\section{Study funding}

This study was supported by grants from the Canadian Institutes of Health Research (201610PJT-377869, MOPG2-341146-159133-BRIDG), Fondation Les Amis d'Elliot, Leuco-Action, Fondation Lueur d'Espoir pour Ayden, Fondation le Tout pour Loo, and Réseau de Médecine Génétique Appliquée of the Fonds de Recherche en Santé du Québec. This research was enabled in part by support provided by Compute Canada (computecanada.ca). The authors acknowledge the McGill University and Genome Quebec Innovation Center. Dr. Bernard has received the New Investigator Salary Award from the Canadian Institutes of Health Research (2017-2022). Dr. Gauquelin has received grants from the Canadian Gene Cure Advanced Therapies for Rare Disease (Can-GARD) and from the R.S. McLaughlin and Teva Canada Innovation funds from the Faculty of
Medicine, Université Laval. Dr. Fribourg is supported by INSERM, CNRS, and the Université de Bordeaux.

\section{Disclosure}

The sponsors did not have any role in the design and conduct of the study; collection, management, analysis, or interpretation of the data; preparation, review, or approval of the manuscript; or decision to submit the manuscript for publication. The DDD study presents independent research commissioned by the Health Innovation Challenge Fund [grant number HICF-1009003], a parallel funding partnership between Wellcome and the Department of Health, and the Wellcome Sanger Institute [grant number WT098051]. The views expressed in this publication are those of the author(s) and not necessarily those of Wellcome or the Department of Health. The study has UK Research Ethics Committee approval (10/H0305/83, granted by the Cambridge South REC, and GEN/284/12, granted by the Republic of Ireland REC). The research team acknowledges the support of the National Institute for Health Research, through the Comprehensive Clinical Research Network. This study makes use of DECIPHER (decipher.sanger.ac.uk), which is funded by the Wellcome. Go to Neurology.org/NG for full disclosures. Funding information is provided at the end of the article.

\section{Publication history}

Received by Neurology: Genetics April 23, 2019. Accepted in final form September 18, 2019.

Appendix Authors

\begin{tabular}{|c|c|c|c|}
\hline Name & Location & Role & Contribution \\
\hline $\begin{array}{l}\text { Laurence } \\
\text { Gauquelin, } \\
\text { MD, FRCPC }\end{array}$ & $\begin{array}{l}\text { McGill University, } \\
\text { Montreal, Canada } \\
\text { The Hospital for Sick } \\
\text { Children, University } \\
\text { of Toronto, Toronto, } \\
\text { Canada }\end{array}$ & $\begin{array}{l}\text { Co- } \\
\text { first } \\
\text { author }\end{array}$ & $\begin{array}{l}\text { Design and } \\
\text { conceptualized the } \\
\text { study; acquisition of } \\
\text { data; analyzed the } \\
\text { data; and drafted the } \\
\text { manuscript for } \\
\text { intellectual content }\end{array}$ \\
\hline $\begin{array}{l}\text { Ferdy K. } \\
\text { Cayami, MD }\end{array}$ & $\begin{array}{l}\text { VU University } \\
\text { Medical Center, } \\
\text { Amsterdam, The } \\
\text { Netherlands } \\
\text { Center for } \\
\text { Biomedical } \\
\text { Research, } \\
\text { Diponegoro } \\
\text { University, } \\
\text { Semarang, Indonesia }\end{array}$ & $\begin{array}{l}\text { Co- } \\
\text { first } \\
\text { author }\end{array}$ & $\begin{array}{l}\text { Designed and } \\
\text { conceptualized the } \\
\text { study; acquisition of } \\
\text { data; analyzed the } \\
\text { data; and drafted the } \\
\text { manuscript for } \\
\text { intellectual content }\end{array}$ \\
\hline $\begin{array}{l}\text { László } \\
\text { Sztriha, MD, } \\
\text { PhD }\end{array}$ & $\begin{array}{l}\text { University of Szeged, } \\
\text { Szeged, Hungary }\end{array}$ & Author & $\begin{array}{l}\text { Acquisition of data } \\
\text { and revised the } \\
\text { manuscript for } \\
\text { intellectual content }\end{array}$ \\
\hline $\begin{array}{l}\text { Grace Yoon, } \\
\text { MD, FRCPC }\end{array}$ & $\begin{array}{l}\text { The Hospital for Sick } \\
\text { Children, University } \\
\text { of Toronto, Toronto, } \\
\text { Canada }\end{array}$ & Author & $\begin{array}{l}\text { Acquisition of data } \\
\text { and revised the } \\
\text { manuscript for } \\
\text { intellectual content }\end{array}$ \\
\hline $\begin{array}{l}\text { Luan T. Tran, } \\
\text { MSc }\end{array}$ & $\begin{array}{l}\text { McGill University, } \\
\text { Montreal, Canada } \\
\text { Research Institute of } \\
\text { the McGill University } \\
\text { Health Center, } \\
\text { Montreal, Canada }\end{array}$ & Author & $\begin{array}{l}\text { Acquisition of data } \\
\text { and revised the } \\
\text { manuscript for } \\
\text { intellectual content }\end{array}$ \\
\hline
\end{tabular}


Appendix (continued)

\begin{tabular}{|c|c|c|c|}
\hline Name & Location & Role & Contribution \\
\hline $\begin{array}{l}\text { Julia Rankin, } \\
\text { MD, PhD }\end{array}$ & $\begin{array}{l}\text { Royal Devon and } \\
\text { Exeter Hospital NHS } \\
\text { Trust, Exeter, United } \\
\text { Kingdom }\end{array}$ & Author & $\begin{array}{l}\text { Acquisition of data } \\
\text { and revised the } \\
\text { manuscript for } \\
\text { intellectual content }\end{array}$ \\
\hline $\begin{array}{l}\text { Richard } \\
\text { Webster, } \\
\text { MBBS, MSc, } \\
\text { FRACP }\end{array}$ & $\begin{array}{l}\text { The Children's } \\
\text { Hospital at } \\
\text { Westmead, } \\
\text { Westmead, New } \\
\text { South Wales, } \\
\text { Australia }\end{array}$ & Author & $\begin{array}{l}\text { Acquisition of data } \\
\text { and revised the } \\
\text { manuscript for } \\
\text { intellectual content }\end{array}$ \\
\hline $\begin{array}{l}\text { Heike } \\
\text { Philippi, MD }\end{array}$ & $\begin{array}{l}\text { Center of } \\
\text { Developmental } \\
\text { Neurology, } \\
\text { Frankfurt, Germany }\end{array}$ & Author & $\begin{array}{l}\text { Acquisition of data } \\
\text { and revised the } \\
\text { manuscript for } \\
\text { intellectual } \\
\text { content }\end{array}$ \\
\hline $\begin{array}{l}\text { Bart van de } \\
\text { Warrenburg, } \\
\text { MD, PhD }\end{array}$ & $\begin{array}{l}\text { Radboud University } \\
\text { Medical Center, } \\
\text { Nijmegen, The } \\
\text { Netherlands }\end{array}$ & Author & $\begin{array}{l}\text { Acquisition of data } \\
\text { and revised the } \\
\text { manuscript for } \\
\text { intellectual content }\end{array}$ \\
\hline $\begin{array}{l}\text { Dagmar } \\
\text { Timmann, } \\
\text { MD }\end{array}$ & $\begin{array}{l}\text { Essen University } \\
\text { Hospital, University } \\
\text { of Duisburg-Essen, } \\
\text { Essen, Germany }\end{array}$ & Author & $\begin{array}{l}\text { Acquisition of data } \\
\text { and revised the } \\
\text { manuscript for } \\
\text { intellectual content }\end{array}$ \\
\hline $\begin{array}{l}\text { Abhijit Dixit, } \\
\text { MD }\end{array}$ & $\begin{array}{l}\text { Nottingham } \\
\text { University Hospitals } \\
\text { NHS Trust, } \\
\text { Nottingham, United } \\
\text { Kingdom }\end{array}$ & Author & $\begin{array}{l}\text { Acquisition of data } \\
\text { and revised the } \\
\text { manuscript for } \\
\text { intellectual content }\end{array}$ \\
\hline $\begin{array}{l}\text { Claire Searle, } \\
\text { MB ChB, } \\
\text { MRCP }\end{array}$ & $\begin{array}{l}\text { Nottingham } \\
\text { University Hospitals } \\
\text { NHS Trust, } \\
\text { Nottingham, United } \\
\text { Kingdom }\end{array}$ & Author & $\begin{array}{l}\text { Acquisition of data } \\
\text { and revised the } \\
\text { manuscript for } \\
\text { intellectual content }\end{array}$ \\
\hline DDD Study & $\begin{array}{l}\text { Wellcome Sanger } \\
\text { Institute, Wellcome } \\
\text { Genome Campus, } \\
\text { Cambridge, United } \\
\text { Kingdom }\end{array}$ & Author & $\begin{array}{l}\text { Acquisition of data } \\
\text { and revised the } \\
\text { manuscript for } \\
\text { intellectual content }\end{array}$ \\
\hline $\begin{array}{l}\text { Nivedita } \\
\text { Thakur, MD }\end{array}$ & $\begin{array}{l}\text { University of Texas } \\
\text { Health Science } \\
\text { Center, Houston, TX }\end{array}$ & Author & $\begin{array}{l}\text { Acquisition of data } \\
\text { and revised the } \\
\text { manuscript for } \\
\text { intellectual content }\end{array}$ \\
\hline $\begin{array}{l}\text { Michael C. } \\
\text { Kruer, MD }\end{array}$ & $\begin{array}{l}\text { Phoenix Children's } \\
\text { Hospital, Phoenix, AZ } \\
\text { Arizona State } \\
\text { University, Tempe, } \\
\text { AZ }\end{array}$ & Author & $\begin{array}{l}\text { Acquisition of data } \\
\text { and revised the } \\
\text { manuscript for } \\
\text { intellectual content }\end{array}$ \\
\hline $\begin{array}{l}\text { Suvasini } \\
\text { Sharma, MD, } \\
\text { DM }\end{array}$ & $\begin{array}{l}\text { Lady Hardinge } \\
\text { Medical College and } \\
\text { Associated Kalawati } \\
\text { Saran Children's } \\
\text { Hospital, New Delhi, } \\
\text { India }\end{array}$ & Author & $\begin{array}{l}\text { Acquisition of data } \\
\text { and revised the } \\
\text { manuscript for } \\
\text { intellectual content }\end{array}$ \\
\hline $\begin{array}{l}\text { Adeline } \\
\text { Vanderver, } \\
\text { MD }\end{array}$ & $\begin{array}{l}\text { Children's Hospital of } \\
\text { Philadelphia, } \\
\text { Philadelphia, PA } \\
\text { University of } \\
\text { Pennsylvania, } \\
\text { Philadelphia, PA }\end{array}$ & Author & $\begin{array}{l}\text { Acquisition of data } \\
\text { and revised the } \\
\text { manuscript for } \\
\text { intellectual content }\end{array}$ \\
\hline $\begin{array}{l}\text { Davide } \\
\text { Tonduti, MD, } \\
\text { PhD }\end{array}$ & $\begin{array}{l}\text { Neurological } \\
\text { Institute C. Besta } \\
\text { Foundation IRCCS, } \\
\text { Milan, Italy }\end{array}$ & Author & $\begin{array}{l}\text { Acquisition of data } \\
\text { and revised the } \\
\text { manuscript for } \\
\text { intellectual } \\
\text { content }\end{array}$ \\
\hline
\end{tabular}

Appendix (continued)

\begin{tabular}{|c|c|c|c|}
\hline Name & Location & Role & Contribution \\
\hline $\begin{array}{l}\text { Kether } \\
\text { Guerrero, } \\
\text { MSc }\end{array}$ & $\begin{array}{l}\text { McGill University, } \\
\text { Montreal, Canada } \\
\text { Research Institute of } \\
\text { the McGill University } \\
\text { Health Center, } \\
\text { Montreal, Canada }\end{array}$ & Author & $\begin{array}{l}\text { Acquisition of data; } \\
\text { analyzed the data; } \\
\text { and revised the } \\
\text { manuscript for } \\
\text { intellectual content }\end{array}$ \\
\hline $\begin{array}{l}\text { François } \\
\text { Hocke, MD } \\
\text { (cand.) }\end{array}$ & $\begin{array}{l}\text { CHU Bordeaux, } \\
\text { Bordeaux, France }\end{array}$ & Author & $\begin{array}{l}\text { Acquisition of data } \\
\text { and revised the } \\
\text { manuscript for } \\
\text { intellectual content }\end{array}$ \\
\hline $\begin{array}{l}\text { Rosalina M.L. } \\
\text { van } \\
\text { Spaendonk, } \\
\text { PhD }\end{array}$ & $\begin{array}{l}\text { VU University } \\
\text { Medical Center, } \\
\text { Amsterdam, The } \\
\text { Netherlands }\end{array}$ & Author & $\begin{array}{l}\text { Acquisition of data } \\
\text { and revised the } \\
\text { manuscript for } \\
\text { intellectual content }\end{array}$ \\
\hline $\begin{array}{l}\text { Eva L. Fung, } \\
\text { MB ChB }\end{array}$ & $\begin{array}{l}\text { The Chinese } \\
\text { University of Hong } \\
\text { Kong, Hong Kong, } \\
\text { China }\end{array}$ & Author & $\begin{array}{l}\text { Acquisition of data } \\
\text { and revised the } \\
\text { manuscript for } \\
\text { intellectual content }\end{array}$ \\
\hline $\begin{array}{l}\text { Stefano } \\
\text { D'Arrigo, MD }\end{array}$ & $\begin{array}{l}\text { Fondazione IRCCS } \\
\text { Istituto Neurologico } \\
\text { C. Besta, Milan, Italy }\end{array}$ & Author & $\begin{array}{l}\text { Acquisition of data } \\
\text { and revised the } \\
\text { manuscript for } \\
\text { intellectual content }\end{array}$ \\
\hline $\begin{array}{l}\text { Gessica } \\
\text { Vasco, MD, } \\
\text { PhD }\end{array}$ & $\begin{array}{l}\text { Bambino Gesu } \\
\text { Children's Hospital, } \\
\text { Rome, Italy }\end{array}$ & Author & $\begin{array}{l}\text { Acquisition of data } \\
\text { and revised the } \\
\text { manuscript for } \\
\text { intellectual content }\end{array}$ \\
\hline $\begin{array}{l}\text { Isabelle } \\
\text { Thiffault, } \\
\text { PhD, FACMG }\end{array}$ & $\begin{array}{l}\text { Children's Mercy } \\
\text { Hospitals and Clinics, } \\
\text { Kansas City, MO } \\
\text { University of } \\
\text { Missouri-Kansas City } \\
\text { School of Medicine, } \\
\text { Kansas City, MO }\end{array}$ & Author & $\begin{array}{l}\text { Acquisition of data; } \\
\text { revised the } \\
\text { manuscript for } \\
\text { intellectual content }\end{array}$ \\
\hline $\begin{array}{l}\text { Dmitriy M. } \\
\text { Niyazov, MD }\end{array}$ & $\begin{array}{l}\text { Ochsner for Children, } \\
\text { New Orleans, LA }\end{array}$ & Author & $\begin{array}{l}\text { Acquisition of data } \\
\text { and revised the } \\
\text { manuscript for } \\
\text { intellectual content }\end{array}$ \\
\hline $\begin{array}{l}\text { Richard } \\
\text { Person, PhD, } \\
\text { FACMG }\end{array}$ & $\begin{array}{l}\text { GeneDx, } \\
\text { Gaithersburg, } \\
\text { Maryland }\end{array}$ & Author & $\begin{array}{l}\text { Acquisition of data } \\
\text { and revised the } \\
\text { manuscript for } \\
\text { intellectual content }\end{array}$ \\
\hline $\begin{array}{l}\text { Kara Stuart } \\
\text { Lewis, MD }\end{array}$ & $\begin{array}{l}\text { Phoenix Children's } \\
\text { Hospital, Phoenix, AZ }\end{array}$ & Author & $\begin{array}{l}\text { Acquisition of data } \\
\text { and revised the } \\
\text { manuscript for } \\
\text { intellectual content }\end{array}$ \\
\hline $\begin{array}{l}\text { Evangeline } \\
\text { Wassmer, } \\
\text { MD, MSc }\end{array}$ & $\begin{array}{l}\text { Birmingham } \\
\text { Children's Hospital, } \\
\text { Birmingham, United } \\
\text { Kingdom }\end{array}$ & Author & $\begin{array}{l}\text { Acquisition of data } \\
\text { and revised the } \\
\text { manuscript for } \\
\text { intellectual content }\end{array}$ \\
\hline $\begin{array}{l}\text { Trine } \\
\text { Prescott, MD }\end{array}$ & $\begin{array}{l}\text { Telemark Hospital, } \\
\text { Skien, Norway }\end{array}$ & Author & $\begin{array}{l}\text { Acquisition of data } \\
\text { and revised the } \\
\text { manuscript for } \\
\text { intellectual content }\end{array}$ \\
\hline $\begin{array}{l}\text { Penny } \\
\text { Fallon, } \\
\text { MBBS, } \\
\text { MRCPCH }\end{array}$ & $\begin{array}{l}\text { St Georges University } \\
\text { Hospital NHS } \\
\text { Foundation Trust, } \\
\text { London, United } \\
\text { Kingdom }\end{array}$ & Author & $\begin{array}{l}\text { Acquisition of data } \\
\text { and revised the } \\
\text { manuscript for } \\
\text { intellectual content }\end{array}$ \\
\hline $\begin{array}{l}\text { Meriel } \\
\text { McEntagart, } \\
\text { MD }\end{array}$ & $\begin{array}{l}\text { St Georges University } \\
\text { Hospital NHS } \\
\text { Foundation Trust, } \\
\text { London, United } \\
\text { Kingdom }\end{array}$ & Author & $\begin{array}{l}\text { Acquisition of data } \\
\text { and revised the } \\
\text { manuscript for } \\
\text { intellectual content }\end{array}$ \\
\hline
\end{tabular}

Continued 


\section{Appendix (continued)}

\begin{tabular}{|c|c|c|c|}
\hline Name & Location & Role & Contribution \\
\hline $\begin{array}{l}\text { Marjo S. van } \\
\text { der Knaap, } \\
\text { MD, PhD }\end{array}$ & $\begin{array}{l}\text { VU University } \\
\text { Medical Center, } \\
\text { Amsterdam, The } \\
\text { Netherlands }\end{array}$ & Author & $\begin{array}{l}\text { Acquisition of data } \\
\text { and revised the } \\
\text { manuscript for } \\
\text { intellectual content }\end{array}$ \\
\hline $\begin{array}{l}\text { Enrico } \\
\text { Bertini, MD }\end{array}$ & $\begin{array}{l}\text { Bambino Gesu } \\
\text { Children's Hospital, } \\
\text { Rome, Italy }\end{array}$ & Author & $\begin{array}{l}\text { Acquisition of data } \\
\text { and revised the } \\
\text { manuscript for } \\
\text { intellectual content }\end{array}$ \\
\hline $\begin{array}{l}\text { Cyril Goizet, } \\
\text { MD, PhD }\end{array}$ & $\begin{array}{l}\text { CHU Bordeaux, } \\
\text { Bordeaux, France }\end{array}$ & Author & $\begin{array}{l}\text { Acquisition of data } \\
\text { and revised the } \\
\text { manuscript for } \\
\text { intellectual content }\end{array}$ \\
\hline $\begin{array}{l}\text { Sébastien } \\
\text { Fribourg, } \\
\text { PhD }\end{array}$ & $\begin{array}{l}\text { Université de } \\
\text { Bordeaux, Bordeaux, } \\
\text { France }\end{array}$ & Author & $\begin{array}{l}\text { Acquisition of data } \\
\text { and revised the } \\
\text { manuscript for } \\
\text { intellectual content }\end{array}$ \\
\hline $\begin{array}{l}\text { Nicole I. } \\
\text { Wolf, MD, } \\
\text { PhD }\end{array}$ & $\begin{array}{l}\text { VU University } \\
\text { Medical Center, } \\
\text { Amsterdam, The } \\
\text { Netherlands }\end{array}$ & $\begin{array}{l}\text { Co- } \\
\text { senior } \\
\text { author }\end{array}$ & $\begin{array}{l}\text { Designed and } \\
\text { conceptualized the } \\
\text { study; acquisition of } \\
\text { data; analyzed the } \\
\text { data; revised the } \\
\text { manuscript for } \\
\text { intellectual content; } \\
\text { and study } \\
\text { supervision }\end{array}$ \\
\hline $\begin{array}{l}\text { Geneviève } \\
\text { Bernard, MD, } \\
\text { MSc, FRCPC }\end{array}$ & $\begin{array}{l}\text { McGill University, } \\
\text { Montreal, Canada } \\
\text { Research Institute of } \\
\text { the McGill University } \\
\text { Health Center, } \\
\text { Montreal, Canada }\end{array}$ & $\begin{array}{l}\text { Co- } \\
\text { senior } \\
\text { author }\end{array}$ & $\begin{array}{l}\text { Designed and } \\
\text { conceptualized the } \\
\text { study; acquisition of } \\
\text { data; analyzed the } \\
\text { data; revised the } \\
\text { manuscript for } \\
\text { intellectual content; } \\
\text { and study } \\
\text { supervision }\end{array}$ \\
\hline
\end{tabular}

\section{References}

1. Kevelam SH, Steenweg ME, Srivastava S, et al. Update on leukodystrophies: a historical perspective and adapted definition. Neuropediatrics 2016;47:349-354.

2. Vanderver A, Prust M, Tonduti D, et al. Case definition and classification of leukodystrophies and leukoencephalopathies. Mol Genet Metab 2015;114:494-500.

3. Parikh S, Bernard G, Leventer RJ, et al. A clinical approach to the diagnosis of patients with leukodystrophies and genetic leukoencephelopathies. Mol Genet Metab 2015; 114:501-515.

4. Steenweg ME, Vanderver A, Blaser S, et al. Magnetic resonance imaging pattern recognition in hypomyelinating disorders. Brain 2010;133:2971-2982.

5. Schiffmann R, van der Knaap MS. Invited article: an MRI-based approach to the diagnosis of white matter disorders. Neurology 2009;72:750-759.

6. Wolf NI, Vanderver A, van Spaendonk RM, et al. Clinical spectrum of $4 \mathrm{H}$ leukodystrophy caused by POLR3A and POLR3B mutations. Neurology 2014;83: 1898-1905.

7. Bernard G, Vanderver A. POLR3-Related leukodystrophy. In: Adam MP, Ardinger HH, Pagon RA, et al, editors. GeneReviews (R). Seattle: University of Washington, Seattle University of Washington, Seattle. GeneReviews is a registered trademark of the University of Washington, Seattle. All rights reserved; 1993

8. La Piana R, Tonduti D, Gordish Dressman H, et al. Brain magnetic resonance imaging (MRI) pattern recognition in Pol III-related leukodystrophies. J Child Neurol 2014; 29:214-220.

9. Tetreault M, Choquet $\mathrm{K}$, Orcesi S, et al. Recessive mutations in POLR3B, encoding the second largest subunit of Pol III, cause a rare hypomyelinating leukodystrophy. Am J Hum Genet 2011;89:652-655.

10. Bernard G, Chouery E, Putorti ML, et al. Mutations of POLR3A encoding a catalytic subunit of RNA polymerase Pol III cause a recessive hypomyelinating leukodystrophy. Am J Hum Genet 2011;89:415-423.
11. Potic A, Brais B, Choquet K, Schiffmann R, Bernard G. 4H syndrome with late-onset growth hormone deficiency caused by POLR3A mutations. Arch Neurol 2012;69:920-923.

12. Daoud H, Tetreault M, Gibson W, et al. Mutations in POLR3A and POLR3B are a major cause of hypomyelinating leukodystrophies with or without dental abnormalities and/or hypogonadotropic hypogonadism. J Med Genet 2013;50:194-197.

13. Gutierrez M, Thiffault I, Guerrero K, et al. Large exonic deletions in POLR3B gene cause POLR3-related leukodystrophy. Orphanet J Rare Dis 2015;10:69.

14. Dorboz I, Dumay-Odelot H, Boussaid K, et al. Mutation in POLR3K causes hypomyelinating leukodystrophy and abnormal ribosomal RNA regulation. Neurol Genet 2018;4:e289.

15. Thiffault I, Wolf NI, Forget D, et al. Recessive mutations in POLR1C cause a leukodystrophy by impairing biogenesis of RNA polymerase III. Nat Commun 2015;6:7623.

16. Dauwerse JG, Dixon J, Seland S, et al. Mutations in genes encoding subunits of RNA polymerases I and III cause Treacher Collins syndrome. Nat Genet 2011;43:20-22.

17. Jay JJ, Brouwer C. Lollipops in the clinic: information dense mutation plots for precision medicine. PLoS One 2016;11:e0160519.

18. Gouy M, Guindon S, Gascuel O. SeaView version 4: a multiplatform graphical user interface for sequence alignment and phylogenetic tree building. Mol Biol Evol 2010, 27:221-224.

19. Tafur L, Sadian Y, Hoffmann NA, et al. Molecular structures of transcribing RNA polymerase I. Mol Cel 2016;64:1135-1143.

20. DeLano WL. Pymol: an open-source molecular graphics tool. CCP4 Newsletter On Protein Crystallography 2002:82-92.

21. Cayami FK, Bugiani M, Pouwels PJW, Bernard G, van der Knaap MS, Wolf NI. 4H leukodystrophy: lessons from 3T imaging. Neuropediatrics 2018;49:112-117.

22. Katsanis SH, Jabs EW. Treacher Collins syndrome. In: Adam MP, Ardinger HH, Pagon RA, et al, editors. GeneReviews (R). Seattle: University of Washington, Seattle University of Washington, Seattle. GeneReviews is a registered trademark of the University of Washington, Seattle. All rights reserved; 1993.

23. Schlump JU, Stein A, Hehr U, et al. Treacher Collins syndrome: clinical implications for the paediatrician - a new mutation in a severely affected newborn and comparison with three further patients with the same mutation, and review of the literature. Eur J Pediatr 2012;171:1611-1618.

24. Teber OA, Gillessen-Kaesbach G, Fischer S, et al. Genotyping in 46 patients with tentative diagnosis of Treacher Collins syndrome revealed unexpected phenotypic variation. Eur J Hum Genet 2004;12:879-890.

25. Vincent $\mathrm{M}$, Geneviève $\mathrm{D}$, Ostertag $\mathrm{A}$, et al. Treacher Collins syndrome: a clinical and molecular study based on a large series of patients. Genet Med 2016;18:49-56.

26. Ghesh L, Vincent M, Delemazure AS, et al. Autosomal recessive Treacher Collins syndrome due to POLR1C mutations: report of a new family and review of the literature. Am J Med Genet A 2019;179:1390-1394.

27. La Piana R, Cayami FK, Tran LT, et al. Diffuse hypomyelination is not obligate for POLR3-related disorders. Neurology 2016;86:1622-1626.

28. Minnerop M, Kurzwelly D, Wagner H, et al. Hypomorphic mutations in POLR3A are a frequent cause of sporadic and recessive spastic ataxia. Brain 2017;140:1561-1578.

29. Gauquelin L, Tétreault M, Thiffault I, et al. POLR3A variants in hereditary spastic paraplegia and ataxia. Brain 2018;141:e1.

30. Minnerop M, Kurzwelly D, Rattay TW, et al. Reply: POLR3A variants in hereditary spastic paraplegia and ataxia. Brain 2018;141:e2.

31. Bauer M, Saldarriaga W, Wolfe SA, Beckwith JB, Frias JL, Cohen MM Jr. Two extraordinarily severe cases of Treacher Collins syndrome. Am J Med Genet A 2013 161A:445-452.

32. Kara B, Köroğlu Ç, Peltonen K, et al. Severe neurodegenerative disease in brothers with homozygous mutation in POLR1A. Eur J Hum Genet 2017;25:315-323.

33. Paolacci S, Li Y, Agolini E, et al. Specific combinations of biallelic POLR3A variants cause Wiedemann-Rautenstrauch syndrome. J Med Genet 2018;55 $837-846$

34. Jurkiewicz E, Dunin-Wạsowicz D, Gieruszczak-Białek D, et al. Recessive mutations in POLR3B encoding RNA polymerase III subunit causing diffuse hypomyelination in patients with $4 \mathrm{H}$ leukodystrophy with polymicrogyria and cataracts. Clin Neuroradiol 2017;27:213-220.

35. Noack Watt KE, Achilleos A, Neben CL, Merrill AE, Trainor PA. The roles of RNA polymerase I and III subunits Polr $1 \mathrm{c}$ and Polr1d in craniofacial development and in Zebrafish models of Treacher Collins syndrome. PLoS Genet 2016;12: e1006187.

36. Farnaes L, Hildreth A, Sweeney NM, et al. Rapid whole-genome sequencing decreases infant morbidity and cost of hospitalization. NPJ Genom Med 2018;3:10.

37. Eldomery MK, Coban-Akdemir Z, Harel T, et al. Lessons learned from additional research analyses of unsolved clinical exome cases. Genome Med 2017;9:26.

38. Fernandez-Tornero C, Moreno-Morcillo M, Rashid UJ, et al. Crystal structure of the 14-subunit RNA polymerase I. Nature 2013;502:644-649.

39. Engel C, Sainsbury S, Cheung AC, Kostrewa D, Cramer P. RNA polymerase I structure and transcription regulation. Nature 2013;502:650-655.

40. Neyer S, Kunz M, Geiss C, et al. Structure of RNA polymerase I transcribing ribosomal DNA genes. Nature 2016;540:607-610. 


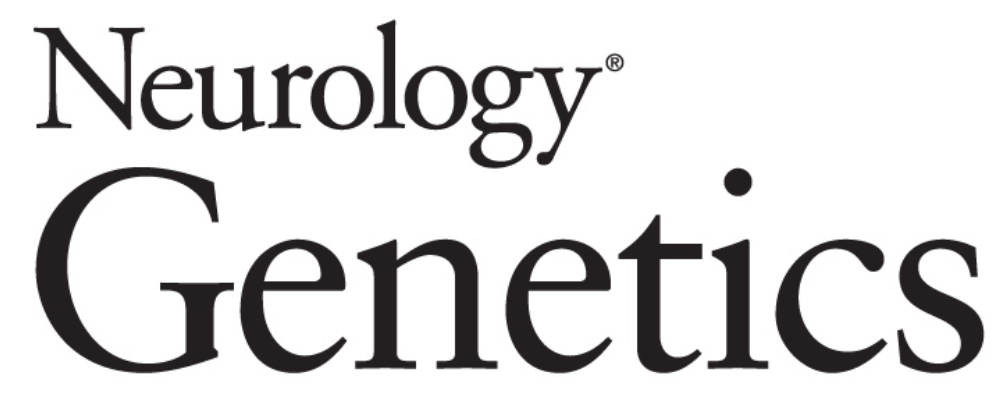
Clinical spectrum of POLR3-related leukodystrophy caused by biallelic POLRIC pathogenic variants
Laurence Gauquelin, Ferdy K. Cayami, László Sztriha, et al. Neurol Genet 2019;5;
DOI 10.1212/NXG.0000000000000369

This information is current as of October 30, 2019

Neurol Genet is an official journal of the American Academy of Neurology. Published since April 2015, it is an open-access, online-only, continuous publication journal. Copyright Copyright @ 2019 The Author(s). Published by Wolters Kluwer Health, Inc. on behalf of the American Academy of Neurology.. All rights reserved. Online ISSN: 2376-7839.

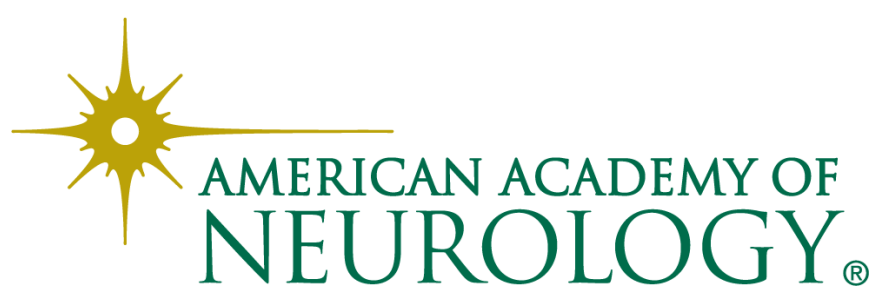




\section{Updated Information \& Services}

References

Citations

Subspecialty Collections

\section{Permissions \& Licensing}

Reprints including high resolution figures, can be found at: http://ng.neurology.org/content/5/6/e369.full.html

This article cites 37 articles, 3 of which you can access for free at: http://ng.neurology.org/content/5/6/e369.full.html\#\#ref-list-1

This article has been cited by 9 HighWire-hosted articles: http://ng.neurology.org/content/5/6/e369.full.html\#\#otherarticles

This article, along with others on similar topics, appears in the following collection(s):

\section{All Genetics}

http://ng.neurology.org//cgi/collection/all_genetics

Endocrine

http://ng.neurology.org//cgi/collection/endocrine

\section{Leukodystrophies}

http://ng.neurology.org//cgi/collection/leukodystrophies

\section{MRI}

http://ng.neurology.org//cgi/collection/mri

Information about reproducing this article in parts (figures,tables) or in its entirety can be found online at:

http://ng.neurology.org/misc/about.xhtml\#permissions

Information about ordering reprints can be found online: http://ng.neurology.org/misc/addir.xhtml\#reprintsus

Neurol Genet is an official journal of the American Academy of Neurology. Published since April 2015, it is an open-access, online-only, continuous publication journal. Copyright Copyright $\odot 2019$ The Author(s). Published by Wolters Kluwer Health, Inc. on behalf of the American Academy of Neurology.. All rights reserved. Online ISSN: 2376-7839.

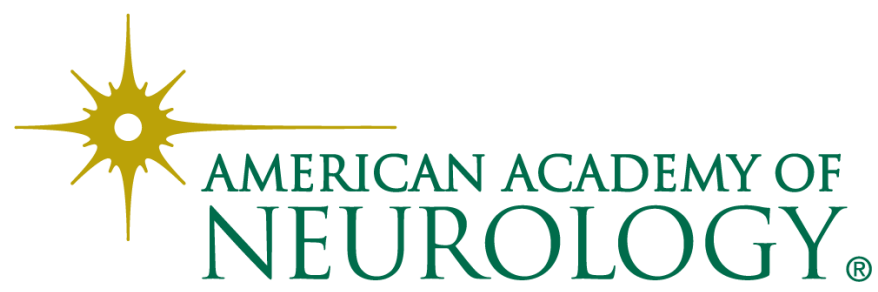

